\title{
Perspectives on Pakistan's, strengths, opportunities and pitfalls trade with China
}

\begin{abstract}
Pakistan and china have historical relationship, both states have strong economic, political, social and defence relations. Both countries were fully supported to their mutual relationships in their foreign policy. In Pakistan, there is massive Chinese investment (infrastructure, roads, highway, ports, and energy and communications sectors). Pakistan welcomed the Chinese investment for social and economic development. China has become Pakistan's largest trading partner in recent years. But Pak-China bilateral trade always remain in favour of China. This paper aims to examine and identify the trade possibilities and issues of imbalance in trade between China and Pakistan. Further, the paper suggests on how to enhance trading relationship between the two countries. For estimation of results Reveal Comparative Advantage (RCA) and Normalized Reveal Comparative Advantage (NRCA) index was used. This article throws light on SWOT analysis compared that's performance of the country in trade to China and which are strengths, weaknesses, opportunities and threats that are being faced by this bilateral trade. Furthermore, this article is an attempt to explore new trends in Pakistan and China relationship.
\end{abstract}

Keywords: China-Pakistan, bilateral trade, RCA and NRCA index, SWOT analysis
Volume 3 Issue $6-2019$

\author{
Tamseela Majeed,' Arshad Mahmood Malik² \\ 'M Phil student, Department of Economics, PMAS-Arid \\ Agriculture University, Pakistan \\ ${ }^{2}$ Assistant Professor, Department of Economics, PMAS-Arid \\ Agriculture University, Pakistan
}

\section{Correspondence: Tamseela Majeed, Arid Agriculture} University, Rawalpindi, Pakistan, Tel 03025080029.

Email tamseelamajeed@gmail.com

Received: September 20, 2019 | Published: November 13, 2019

\section{Introduction}

Agriculture sector is backbone of Pakistan economy, with annual contribution of 19.8 percent in GDP and provision of employment to 42.3 percent labour force of the country. Exports by Pakistan mainly depend upon agro based industrial products. Pakistan is facing serious issue of trade deficit. Perishable goods trade will improve under CPEC due to reduction in distance, ${ }^{1}$ while post-harvest losses in case of fruits and vegetables sector is negatively affecting export surplus. ${ }^{2}$ Rice export is supporting Pakistan instead of cotton. ${ }^{3}$

China has enormous potentials for bilateral trade and investment in huge quantities which can be fruitful to form economic relations to reduce the trade balance with Pakistan on the basis of friendship. The trade and trade ties between the two countries have been established since January 1963 when the two countries held their first bilateral long-term trade agreement (Ministry of Finance, 2014). China has become Pakistan's largest trading partner in recent years. Pakistan and China signed the FTA in 2006 and entered into force in 2007. The agreement was concluded in two parts with the first phase ending in December 2012 and the second stage negotiations starting in July 2013. The agreement aimed at bilateral trade worth $\$ 20$ billion between Pakistan and China at the end of the second phase. ${ }^{4}$

Both countries agreed to set a target of raising bilateral trade to 20 billion dollars in the next three years and maintain the momentum of their mixed-use cooperative partnership, which was the result of frequent bilateral exchanges that took their place at various levels. ${ }^{5}$

\section{Pak-China trade dynamics}

China can build a winning association in its target market by providing common benefit to its counterparts. The international community is on the edge of a unique opportunity to ensure a global development agenda. Pak-China has a unique continuity in the field relation to the interests and multilateral cooperation which has won the vicissitudes in the field. China's investment in several areas and regions is appreciated for self-esteem thus, Pakistan's export potential has not been improved. Furthermore, trade ties fall to a preferential level and the fact is that China has a $\$ 12$ billion trade attitude despite Free Trade Agreements (FTAs) on several rims. ${ }^{5}$

Pak-China bilateral Trade always remains in favour of China. Below Figurel illusrates that the trade situation of Pakistan with China respectively, this is evidence from the trend imports of Pakistan goes high from the last fifteen years, but after the year 2013 sharply increased the volume of Pakistan. Although China has bigger trading partner of Pakistan, but China gained more benefits of bilateral trade between Pak-China trade.

According to the Tanya State "Exorcist" Magazine, in 2015 it is estimated that the overall growing Muslim country in Pakistan has also increased GDP growth by 5.7\%. Muslim countries like Malaysia, Indonesia, Egypt and Turkey are below Pakistan in economic development. China has drawn attention not only because of its rapid economic growth and access to the WTO but also because of its proactive attitude towards regional economic development. China has benefited immensely after signing Free Trade Agreements. ${ }^{6}$

\section{Roads towards free trade agreements}

The effects of Free Trade Agreements between Pakistan and China was unsuccessful with tariff hurdles because Pakistan economy is mostly dependent on international trade as compared to China economy, since the local markets demand is greater than local supply of commodities in the Country. ${ }^{7}$ The outcomes of decreasing in trade obstacles and technological advancement world wise exports level has been enhance that's helpful to expansions in production level and inventive in comparative advantage patterns in global economies. Asian economies such as ASEAN countries and China are enjoying 
an outstanding achievement in changing situations across the globe. Pakistan also has huge potential for enhance growth level but some obstacles for example political instability and lack technological advancement are major factors behind the way of advancement. ${ }^{8} \mathrm{China}$ has extensive gains after validation the Free Trade Arrangements. China has established win-win relationships in its targeted market by providing common benefits to its counterparts. Figure 1 shows that rapidly increases in exports of Pakistan that's are plus point I Pakistan trade but a negative balance for Pakistan. This is the worrying situation for Pakistani Government, to discuss with Chinese officials for reducing the tariff at maximum level. The FTA between China and America will officially come into under the deal, both countries will eliminate tariff on more than 90 percent of highly traded goods. ${ }^{9}$ That is what Pakistan seeks from China an elimination of tariff should be on highly traded goods not at the limited goods.

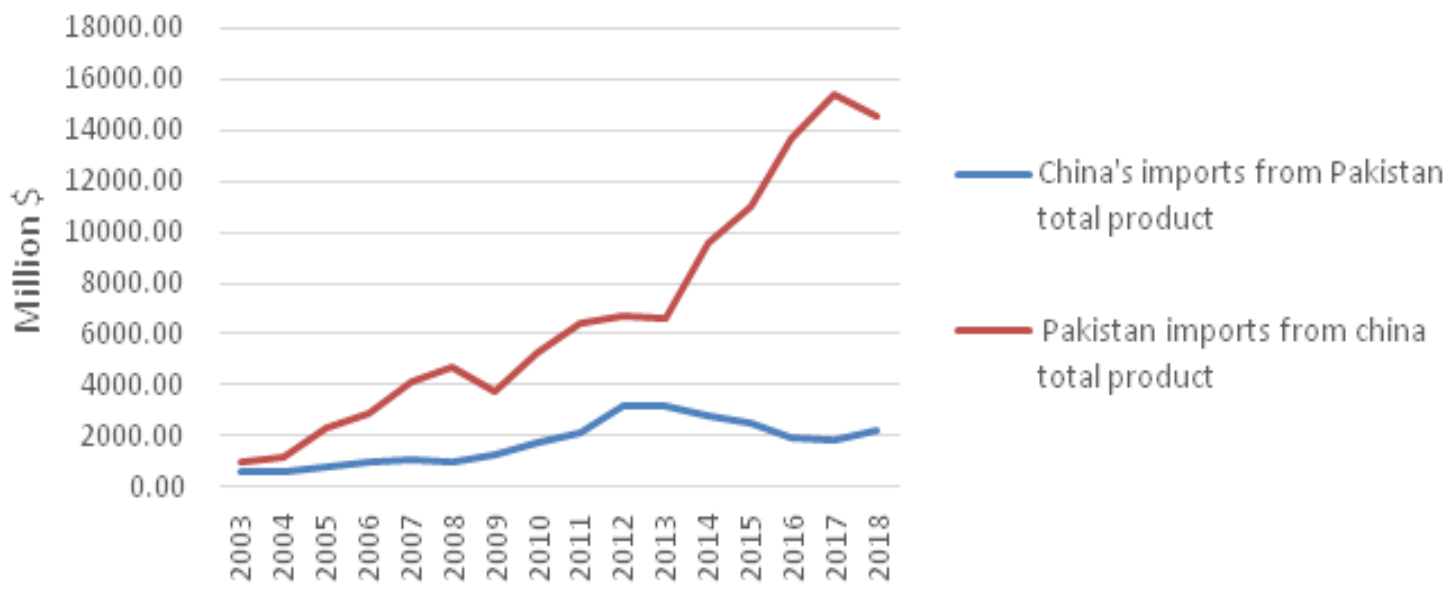

Figure I Recent Trends and Bilateral Trade Possibilities.

\section{Material and methodology}

\section{Data source}

Data was collected from the recent sources relevant to nature of the research problem. For the research purpose data was collected from Trade Map, Federal Bureau of Statistics, FAOSTAT and World Bank. The variables of study included that total exports and imports of Pakistan, total Agricultural imports and exports of Pakistan and major exports and imports of Pakistan from the period of (2003-2018).

\section{Comparative advantages through RCA and NRCA}

The Comparative Advantage played the important role in empirical trade research. Revealed Comparative Advantage index (RCA) can be used for calculation of comparative advantage from trade, for the efficient and effective utilization of resources. ${ }^{10}$ Bangladesh has a comparative advantage in home production of rice. ${ }^{11}$

\section{Reveal Comparative Advantage (RCA)}

Balassa $^{10}$ developed RCA index for comparing the performance of the country in export of a commodity in relation to a group of referenced countries with the help of observed export pattern or revealed data. Revealed comparative advantage index (RCA) was used in order to check, whether the selected sub-sector has comparative advantages or not? The traditional measure of RCA is given by:

$$
R C A=X_{i, j} / \sum X_{j} / X_{i, w} / \sum X_{w}
$$

Here,

$\mathrm{X}_{\mathrm{i}, \mathrm{j}}=$ Exports of good I by Country $\mathrm{J}$

$\sum X_{j}=$ total exports by country

$\mathrm{X}_{\mathrm{i}, \mathrm{w}}=$ World exports of good $\mathrm{i}$ $\sum X_{w}=$ total world exports

If the value of RCA greater than 1 that's show the particular good (sector) has comparative advantage further more if its value less that's show the particular good (sector) has disadvantage.

\section{Normalized rvealed comparative advantages}

Another way of solution was normalized comparative advantages

$$
\operatorname{NRCA}_{j}^{i}=\frac{E_{j}^{i}}{E}-\frac{E_{j} E^{i}}{E E}
$$

Here $E_{j}^{i}$ is country I's of exports of commodity $j, E_{j}^{i}$ exports of commodity $\mathrm{J}$ by all countries, $\mathrm{E}^{\mathrm{i}}$ is country I's exports of all commodities, and $\mathrm{E}$ is exports of all commodities by all countries.

\section{Results and discussion}

Pakistan is an open economy therefore international trade can highly affected it. An imports value of Pakistan is greater than value of exports.

\section{Pak- China trade relationship}

Pakistan is an agro base economy, therefore agriculture commodities are major part of total exports, and it's played crucial role in foreign exchange earnings. ${ }^{12}$ Pakistan has revealed comparative advantages in cotton production that showed a positive profit at market prices. ${ }^{13}$ Below the Table1 illustrated, that Broadly Pakistan exports to china are Cotton, Copper and articles and ores, slag and ash. Cotton contributes a major portion of total exports earning. In present term the share of major export product in Pakistan total exports to China between 64 percent. In which the highest percentage is cotton 43.58 percent and share of Copper and articles thereof, Ores, slag and ash are $13.16,7.42$ percent in 2018 . 
China is large supporter of Pakistan in development of technology, infrastructure and defence sectors. ${ }^{14}$ China said the two sides are working to fully utilize their free trade agreements on goods, investment and services. He also said, "We have requested the Chinese government and the private sector to help strengthen our capacity in the field of processing and manufacturing, textile, leather products, clothing and light engineering."'(Khan, 2012), below the Table 2 show that major imports of Pakistan to China are Electrical machinery and equipment and parts thereof; sound recorders and reproducers, television ...,Machinery, mechanical appliances, nuclear reactors, boilers; parts thereof and Iron and steel. The share of major imports product of Pakistan to China is in- between 50 percent during year 2018. In which the highest percentage is recorded Electrical machinery and equipment and parts thereof; sound recorders and reproducers, television ... is 21.22 percent and share of Machinery, mechanical appliances, nuclear reactors, boilers; parts thereof and articles thereof, are Iron and steel 21.21, 7.16 percent in 2018.

Table I Major China's exports to Pakistan, 2018

\begin{tabular}{lll}
\hline Products & Million dollar & Percentage \\
\hline Cotton & 950.046 & 43.58 \\
Copper and articles thereof & 286.962 & 13.16 \\
Ores, slag and ash & 161.907 & 7.427 \\
other commodities & 780.902 & 35.82 \\
Total & & 100 \\
\hline
\end{tabular}

Source:Author calculation from time-series

Table 2 Major China Imports from Pakistan, 2018

\begin{tabular}{lll}
\hline Products & Million dollar & Percentage \\
\hline $\begin{array}{l}\text { Electrical machinery and equipment and parts thereof; sound recorders } \\
\text { and reproducers, television ... }\end{array}$ & 3087.47 & 21.23 \\
Machinery, mechanical appliances, nuclear reactors, boilers; parts thereof & 3085.93 & 21.22 \\
Iron and steel & 1042.76 & 7.17 \\
Other commodities & 7328.53 & 50.39 \\
Total & & 100 \\
\hline
\end{tabular}

Source:Author calculation from time-series

In the initial years export from Pakistan was larger. During the Korean War, Pakistan's exports of cotton and jute grew but soon fell back to pre-War levels. A major item of export of Pakistan was cotton items, which had a huge market in China. ${ }^{15}$ Figure 2 shows trend of total value of major exports (cotton and copper and articles thereof) to China, (2003-2018); if we compare trade Pakistan had with selected major commodities, below figure depicts that cotton items shares relatively more as compare to other commodities. It will not be exaggerated to say that Pakistan's export is heavily dependent on export of cotton items. This is evidence from the trend exports cotton goes high form the last thirteen years, but after the year 2013 sharply decreased the export of cotton and after 2016 to 2018 constant trend, similarly the trend of exports of copper and articles there of show that from the last six years its exports level increased but during 20052008 sharply exports level of copper and articles thereof decreased, but after 2008 its exports level sharply increased and still it show increasing trend.

China has one of the highest five import sources of Pakistan. Pakistan's major imports from China are machinery, chemicals other textile products, stationery, and construction materials etc. Imports from China also increased from US\$ 1.84 billion in 2004-2005 to US\$ 4.69 billion in 2007to 2008 that showing an average increase of 55\% per year, Textile machinery and electrical appliances are the major parts of overall exports. ${ }^{16}$ Figure 3 shows the trend of the figure of electrical machinery and equipment, mechanical appliance and iron and steel, electrical machinery show that constant trend within the little flection. The figure of imports Pakistan of iron and steel also show constant trend within smell flection. The figure of imports of Pakistan of machinery, mechanical appliance show that during last nine years constant trend, within 2009-2010 sharply its level of imports increased but after 2010 this trend show sharply downward trend and still it has shown constant trend.

\section{RCA and NRCA for exports of Copper and articles thereof, Ores, slag and ash and cotton}

Estimating the export competitiveness this sub-sector has export comparative advantage are not as revealed by the RCA values, if RCA values greater than one or positive NRCA values for the last ten years. That's means this sub-sector gradually gained this competitiveness, bellow the Table 3 illustrates, Copper and articles thereof gradually values of RCA and NRCA shows Fluctuation could be seen for this sub-sector over the period of last fifteen years. Calculation of RCA and NRCA indicates for Ores, slag and ash exports fluctuation could be seen for this sub-sector over the period of last fifteen years.

The RCA and NRCA ratio for exports of cotton possess that this sub-sector gradually gained this competitiveness from RCA value of 3.71 in 2003 to 3.21 in 2017. Export competitiveness remained highest during 2009 with RCA value of 4.00, Means that the ratio of its share in domestic market to the World market has increased with the passage of time. 


\section{Pakistan Exports to China}

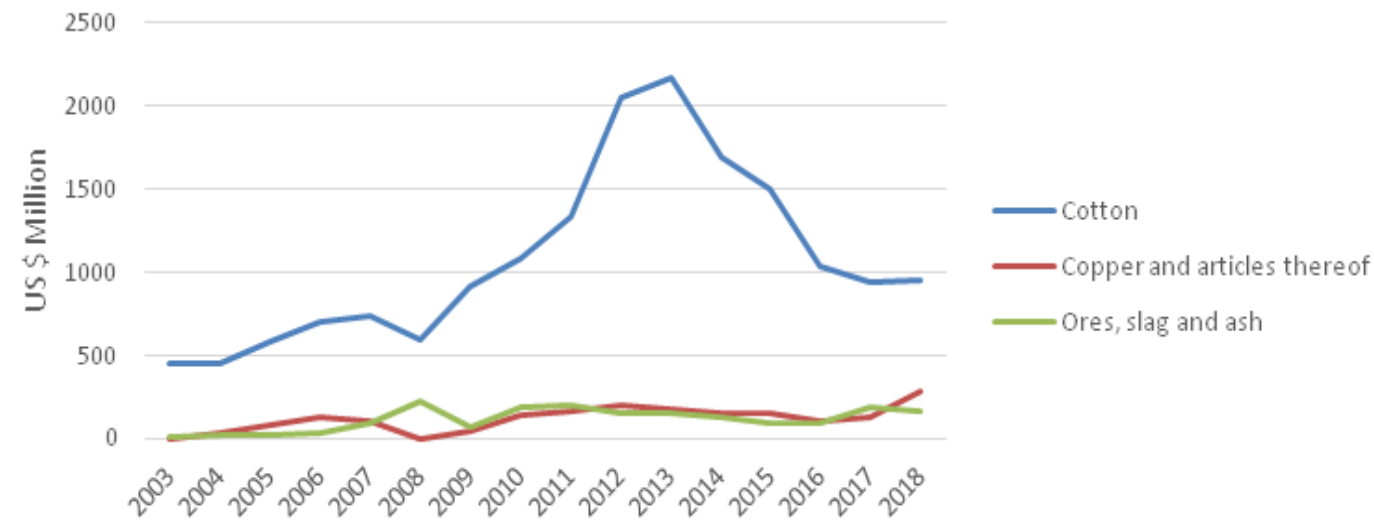

Figure 2 Trend of total value of major Exports to China, (2003-20 I8).

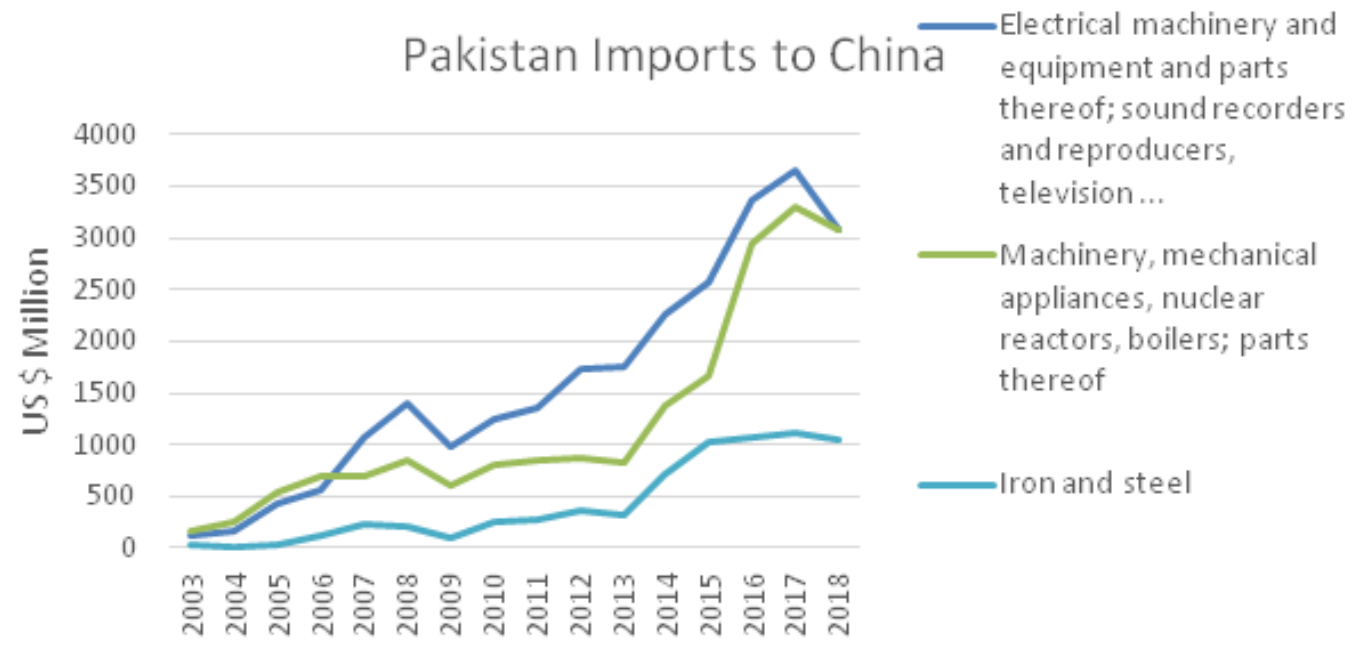

Figure 3 Trend of total value of Imports to China, 2003-20I8.

Table 3 RCA and NRCA of exports of Copper and articles thereof, Ores, slag and ash and cotton

\begin{tabular}{|c|c|c|c|c|c|c|}
\hline Years & $\begin{array}{l}\text { RCA exports of } \\
\text { Copper and articles } \\
\text { thereof }\end{array}$ & $\begin{array}{l}\text { NRCA Copper and } \\
\text { articles thereof }\end{array}$ & $\begin{array}{l}\text { RCA OF Ores, } \\
\text { slag and ash }\end{array}$ & $\begin{array}{l}\text { NRCA Ores, } \\
\text { slag and ash }\end{array}$ & $\begin{array}{l}\text { RCA OF exports } \\
\text { of cotton }\end{array}$ & $\begin{array}{l}\text { NRCA OF } \\
\text { cotton }\end{array}$ \\
\hline 2003 & 0 & -1 & 0.02 & -0.96 & 3.71 & 0.58 \\
\hline 2004 & 0.01 & -0.97 & 51.53 & 0.96 & 3.31 & 0.54 \\
\hline 2005 & 46.76 & 0.96 & 52.32 & 0.96 & 3.26 & 0.53 \\
\hline 2006 & 41.39 & 0.95 & 68.45 & 0.97 & 3.31 & 0.54 \\
\hline 2007 & 44.89 & 0.96 & 17.88 & 0.89 & 3.45 & 0.55 \\
\hline 2008 & 41.25 & 0.95 & 0.35 & -0.49 & 3.35 & 0.54 \\
\hline 2009 & 0.7 & -0.17 & 8.61 & 0.79 & 4 & 0.6 \\
\hline 2010 & 6.9 & 0.75 & 10.3 & 0.82 & 3.35 & 0.54 \\
\hline 2011 & 12.97 & 0.86 & 17.27 & 0.89 & 3.13 & 0.52 \\
\hline 2012 & 6.81 & 0.74 & 12.64 & 0.85 & 3.07 & $0.5 I$ \\
\hline 2013 & 9.33 & 0.81 & 10.05 & 0.82 & 3.2 & 0.52 \\
\hline
\end{tabular}


Table continued

\begin{tabular}{|c|c|c|c|c|c|c|}
\hline Years & $\begin{array}{l}\text { RCA exports of } \\
\text { Copper and articles } \\
\text { thereof }\end{array}$ & $\begin{array}{l}\text { NRCA Copper and } \\
\text { articles thereof }\end{array}$ & $\begin{array}{l}\text { RCA OF Ores, } \\
\text { slag and ash }\end{array}$ & $\begin{array}{l}\text { NRCA Ores, } \\
\text { slag and ash }\end{array}$ & $\begin{array}{l}\text { RCA OF exports } \\
\text { of cotton }\end{array}$ & $\begin{array}{l}\text { NRCA OF } \\
\text { cotton }\end{array}$ \\
\hline 2014 & 10.94 & 0.83 & 13.13 & 0.86 & 3.22 & 0.53 \\
\hline 2015 & 14.46 & 0.87 & 16.08 & 0.88 & 3.31 & 0.54 \\
\hline 2016 & 29.82 & 0.94 & 12.62 & 0.85 & 3.17 & 0.52 \\
\hline 2017 & 10.28 & 0.82 & 14.13 & 0.87 & 3.21 & 0.52 \\
\hline 2018 & 6.9 & 0.75 & 37.37 & 0.95 & 2.94 & 0.49 \\
\hline
\end{tabular}

Source:Author's calculation from time-series

\section{SWOT Analysis of PCFTA}

Abbreviation of SWOT (Strengths, Weaknesses, Opportunities and Threats). It is very simple method for analyses effect of variables between countries. Here we compared the performance of the country in trade to China and which are strengths and weaknesses further more what's opportunities and threats are faced this bilateral trade. Below the Figure 4 shows all aspects of SWOT and also demonstrates the internal or domestic market effects and external effects of PCFTA.

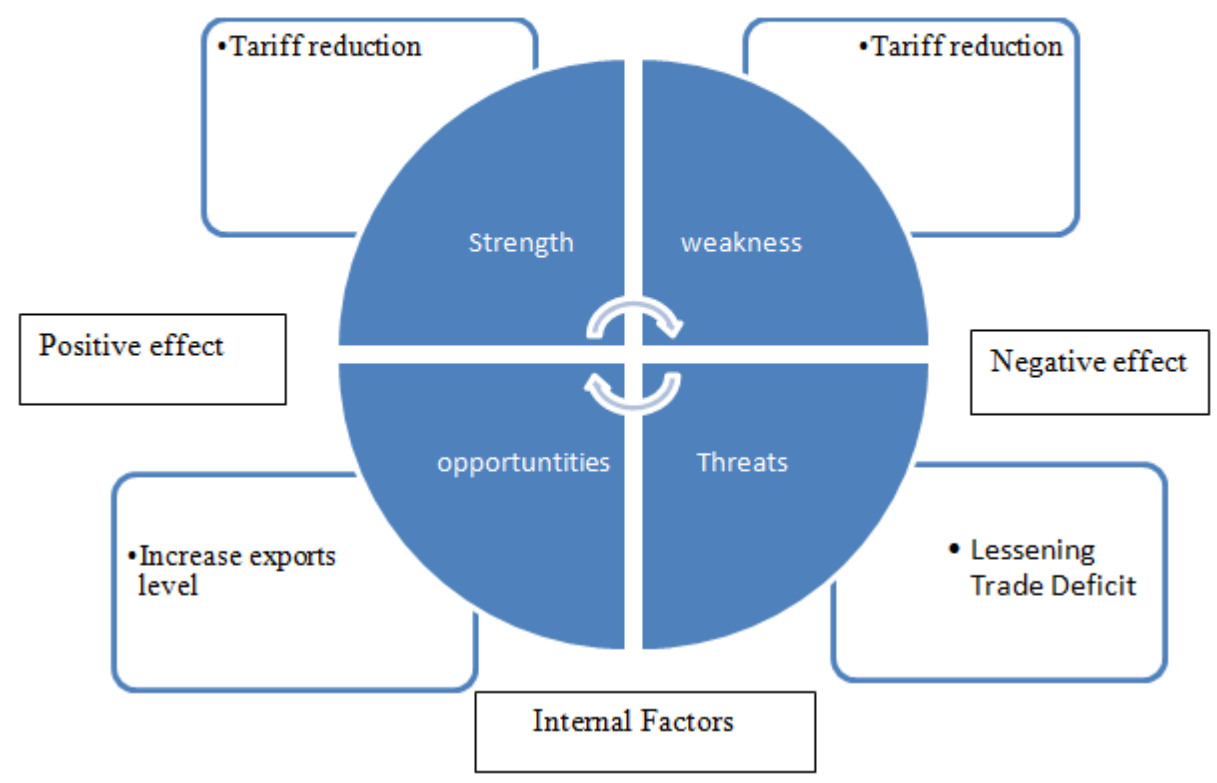

Figure 4 SWOT (strengths, weaknesses, opportunities, threats).

\section{Strengths}

The strength of free trade agreement from Pakistan's viewpoint is that's overall growth in exports to China, we attained considerable progress during previous years. Performance of exports along each concern category has been stable, even one challenge that the value of exports are not significant as compared to imports from China or even Pakistan's exports to the world. The strength of the FTA relies upon the opportunities it considers to run in the future for Pakistan and the doors it has opened for trade which Pakistan could have possible advantage to given that it diversifies its production composition and increases its capacity while China provides it competitive tariff concessions via further trade negotiations.

\section{Weaknesses}

Huge difference in size of both economies and their growth in the world trade, further vaster gap in level of industrial development and the relatively unequal contribution of trade made by each country, the logic behind an FTA was to strengthen relations through providing deeper access into each other's markets. Such however could not be achieved, furthermore narrow coverage of this FTA, other FTAs signed by China with over eight countries and regions give hefty concessions, making Pakistan's products inconsequential by design, in the Chinese markets. The ASEAN countries enjoy tariff elimination coverage of over $90 \%$ traded goods. 


\section{Opportunities}

China and Pakistan to maintain all-weather friendship for stability. Their geographical ability spreads their complete relationship to the geo-economic potential. To exploit the benefits of their shared borders the two sides completed the legendary Kur Korum Highway (KKH) in 1982 which linked China's Kashmir to Islamabad via Kajawah Pass. During 2000s the highway was extended and modernized to work for this kind of traffic until the modern year. Internal road network connects KHH with Pakistan Gwadar and Karachi ports in the south of the country Pakistan Economic Corridor (CPEC) China has made commitments to Invest around $\$ 46$ billion in development deals, which is equivalent to roughly 20 per cent of Pakistan's annual GDP (Stevens, 2015).China's biggest foreign direct investment deal to invest in Pakistan. In total, the economic corridor project aims to add some 17,000 megawatts of electricity generation at a cost of around $\$ 34$ billion. ${ }^{17}$

\section{Conclusion}

Pakistan is Agri-based economy, it contributed one fifth to GDP of the country, within the growing large population of the country required strong policy framework for agriculture sector , because this sector is only the domestic source of earning, it's a major source of foreign exchange. The previous results of research on base of RCA and NRCA show that during 2003 to 2018 agricultural commodities (cotton, Copper and articles thereof and cru stances Ores, slag and ash) exports of Pakistan, gradually gained in cotton competitiveness from RCA values increase in its exports Competitiveness with less or more fluctuation during the fifteen years. Increased market competitiveness of Pakistani agricultural commodities in global market was a healthy sign for the economy; furthermore Pakistan has great potential to increase our exports.

The trend of major imports of Pakistan (Preparations of meat of fish or of cur stances, mollusc or other aqt iron and steel, electrical machinery, mechanical appliance)show that during 2003 to 2018 commodities evaluated that, mollusc or other aq goes mostly constant situation last fifteen years but during year 2018 its level of imports can increased. The figure of electrical machinery and equipment show that constant trend within the less flection. The figure of imports Pakistan of iron and steel also show constant trend within smell flection. The figure of imports of Pakistan of machinery, mechanical appliance show that during last nine years constant trend, within 2009-2010 sharply its level of imports increased but after 2010 this trend show sharply downward trend and still it has shown constant trend. Although Pakistan and China are bigger trade partners .Pakistan also signed many free trade agreements with china through this agreements military and technological transactions can easily possible ,but Pakistan can faced the Trade deficit situation in Pak-china trade. China Played important role increase the investment .For Pakistan economy, the most important development is China-Pakistan corridor (CPEC) has completely changed the situation.

\section{Policy and recommendations}

- Pakistan should raise the opportunity of exporting agricultural commodities to developing less developed countries too.

- Product differentiation and quality features is another complex area, Pakistan should highly focused on quality of commodities for maximum achievement from trade.
- Pakistan must review her trade policy in terms of commodity divergence and main focused on domestic policies.

- Security concern has been the most important challenge to CPEC, and CPEC played important role in enhance to trade between Pakistan and China, so government should take immediate and necessary actions to trickle this problem.

\section{Acknowledgments}

None.

\section{Conflicts of interest}

The author declares no conflicts of interest.

\section{Funding}

None.

\section{References}

1. Chaudhry IS, Gulzar F, Ahmad HG, et al. Impact of China-Pakistan Economic Corridor (CPEC) on Pakistan's trade: Empirical Evidence from Gravity Model. Review of Economics and Development Studies. 2017;3(1):29-38.

2. Ahmad B, Mehdi M, Ghafoor A, et al. Value chain assessment and measuring export determinants of citrus fruits in Pakistan: an analysis of primary data. Pakistan Journal of Agricultural Sciences. 2018;55(3):691-698.

3. Hussain E, Haq M. Pakistan Export Earnings-Analysis Villalta 20092011. Pakistan Journal of Engineering, Technology \& Science. 2016;2(1).

4. FAO FAO Yearbook: Production. FAO, 2004.

5. Irshad MS. One belt and one road: dose China-Pakistan economic corridor benefit for Pakistan's Economy? Journal of Economics and Sustainable Development. 2015;6(24):8.

6. Asyrofi S. Model, Strategies \&Permainan Edukatifdalam Pembelajaran Bahasa Arab. 2014.

7. Irshad MS. SWOT analysis of Pakistan-China free trade agreement: Pros and Cons. International Journal of Asian Social Science. 2017;7(1):4553.

8. Mustafa A, Qayyum A, Hera NE. Impact of Technical Barriers to Trade on Trade between China and Pakistan. Pakistan Development Review. 2017;56(4):235-251.

9. Chiang MH. The potential of China-Japan-South Korea free trade agreement. East Asia. 2013;30(3):199-216.

10. Balassa B. Trade Liberalisation and "Revealed" Comparative Advantage 1. The Manchester school. 1965;33(2):99-123.

11. Shahabuddin Q, Dorosh PA. Comparative advantage in Bangladesh crop production. International Food Policy Research Institute. 2002.

12. Wasim MP. Major Exports of Pakistan: Their Growth and Instability. Journal of Economic Cooperation Among Islamic Countries. 1998;9(3):55-66.

13. Faruqee H. Pricing to market and the real exchange rate. Staff Papers. 1995;42(4):855-881.

14. Council PB. Preliminary study on Pakistan and China trade partnership post-FTA”. Unpublished manuscript. 2013.

15. Kumar A. China-Pakistan economic relations. Institute of Peace and Conflict Studies, special report, 30, 2006;66. 
16. Memon NA. Pak-China economic and trade relations. Balance. $2005 ; 6: 436-439$.
17. Stantchev V, Barnawi A, Ghulam S, et al. Smart items, fog and cloud computing as enablers of servitization in healthcare. Sensors \& Transducers. 2015;185(2):121. 